\title{
Riding the Coronacoaster: Learning, Teaching, and Living at a Health Sciences Campus during the COVID-19 Pandemic
}

Angie Mejia, PhD, Chandi Katoch, Fiza Khan, Blake Peterson, and Daniel R. Turin

This is the submitted version of an article forthcoming in a special issue of the journal Anthropologica on COVID-19. Questions should be directed to the corresponding author, Angie Mejia, via email at amejiame@r.umn.edu

Suggested citation:

Mejia, Angie, Chandi Katoch, Fiza Khan, Blake Peterson, \& Daniel R. Turin. 2020. Riding the Coronacoaster: Learning, Teaching, and Living at a Health Science Campus During the COVID- 19 Pandemic. Anthropologica. [Forthcoming]

\begin{abstract}
This collaborative autoethnography examines how we (four students and a professor of communityengaged research) used our experiences to make sense of life during COVID 19. Engaging in a collective approach to autoethnographic writing, we highlight different perspectives of a cultural moment shaped by the science denialism and untruths that define US governmental practices and approaches to the pandemic. We share how we are dealing with COVID 19 discourses that run counter to the scientific foregrounding of our STEM (Science, Technology, Engineering, and Math) and health and medical sciences training, reflect on the role of the pandemic in shifting post-baccalaureate plans, navigate the lockdown while participating in racial justice protests in Minneapolis, and examine the experiences of being essential healthcare workers while in school. By situating these shifting ways of learning, teaching, and engaging as portents of the difficulties we may continue to face, we show the possibilities of narrative methods in imagining and implementing post-pandemic healthcare practices grounded on a praxis of community justice and collective care.
\end{abstract}

Keywords: Collaborative Autoethnography, COVID 19, Health Sciences, STEM education, Pre-med 


\section{Introduction}

This text contributes to an ongoing archiving of experiences and perspectives from healthcare students, workers, and educators (Ansari 2020, Raimondi 2020, Yarrow and Pagan 2020, Mejia 2020) making sense of a pandemic. The question framing our inquiry: What do our experiences navigating COVID-19 tell us about the shared urgency and need for new ways of doing, feeling, and insisting on a better world? Our methodological approach to answering this, a collaborative autoethnography, documents a shared sense of rapid emotional shifting, shaped by our different social identities and roles at a health sciences university campus in Minnesota. In documenting this shared emotional landscape - fears of disease transmission vis-à-vis our desire to work in our respective fields, feelings of exasperation when communicating health information to unwilling publics, mourning lost opportunities and community, and the anger and helplessness of uncertainty-we argue that, instead of creating a "new normal," those of us straddling the worlds of health and community, should document, demand, and imagine ways to begin anew.

We did not originally set out to write a collaborative autoethnography on COVID-19. We, Fiza, Blake, and Daniel, were signed up to take a class on community engagement, taught by Professor Angie Mejia, with Chandi as the class's teaching assistant. Changes to our university's IRB in response to COVID-19 meant that our original plan to collect and analyze mixed-methods data on emotional health, historically marginalized minoritized and racialized communities, and communitybased gardening would not be possible. Our first instinct was to meet and talk about future research projects to engage in once the pandemic passed. However, we realized that our unique perspectives and lived realities as members of a health sciences campus in Minnesota were not only unique due to our different social positionalities but that similar narratives had not been highlighted in the emerging academic literature on COVID-19. 
As a research approach, autoethnography is the act of "describ[ing] and systematically analyz[ing] (graphy) personal experience (auto) to understand cultural experience (ethno)" (Ellis 2004, Holman Jones 2005, as cited in, Ellis, Adams and Bochner 2010). Most of us, excluding Professor Angie, were only introduced to reflective writing during our Senior Capstone reflection and proposal writing class. As she indicated, autoethnographic writing would differ from the type we had been introduced to in this class. As autoethnographers, we would be writing with the intention (Holman Jones, Adams and Ellis, Introduction: Coming to Know Autoethnography as More than a Method 2013) of mapping the links between our experiences and perspectives of navigating a COVID-19 summer to the national responses and reactions of those around us. We would also be adding to existing knowledge of how particular groups, in our case, of people training to go into the health sciences field, were experiencing the pandemic. This would mean becoming vulnerable to each other and those who would read our work while hoping that our writing might stimulate further conversations and actions towards social change. The methodological choices that comprise an autoethnographic text-“"purposefully commenting on/critiquing of culture and cultural practices, ... making contributions to existing research, ... embracing vulnerability with purpose, and ... creating a reciprocal relationship with audiences in order to compel a response" (Holman Jones, Adams and Ellis 2013, 24, emphasis on the original) —would help us collectively analyze our experiences as graduating seniors planning for future postbaccalaureate training in health and medical sciences during a volatile socio-political moment that undermined scientific knowledge and practices that we were learning in our classes and applying within our perspective internships and workplaces.

As a collaborative autoethnography (Chang, Ngunjiri and Hernandez 2016), Professor Angie Mejia would be asking us to systematically share and reflect on all of our experiences, on epiphanous moments, from the pandemic's onset to the present. While incorporating visuals, we would write short, 
evocative individual journal entries on how we were experiencing and reacting to the social changes connected to COVID-19. We would then meet as a group and analyze all of these textual pieces to discern patterns, focusing on those moments of shared recognition. We also took into consideration our responsibilities to others and other projects as we chose which aspects and stages of this research project we could realistically dedicate time to and in what capacity we could do so. These stages included not only writing our reflections but the subsequent analysis of these reflections. Coding, preliminary distilling of, and writing up of themes, as well as manuscript writing, would be divided among us. Thus, some of us took on the bulk of the initial data coding, segmentation, and analysis, while others worked on the literature review. At the same time, we as a group read, discussed, and heavily critiqued all of our data and written up analyses and engaged with every analytical iteration of the themes that were emerging. Most of us met weekly via Zoom, from the middle of May until the end of August. Some of us paired up and, depending on the stage of research we decided to collaborate in, met more frequently. We also communicated as a group via email, social media, or group text.

As with many collaborative efforts, not all findings from the analysis are presented in this text. Even though the sections do not encapsulate every idea from our laborious analysis of written reflections and additional data in the form of pictures, social media snippets, and the like, we chose to write about those moments that highlighted our collective sense of ambiguity and epiphanous moments that spoke to our shared metaphor of experiencing COVID-19 as a rollercoaster. Hence, the title of this article. The rest of our experiences, along with those of our university's students, staff, and faculty, are currently being collected as video narratives and archived as part of an ongoing campus-wide effort by the corresponding author. 


\section{Denial}

23 February 2020: My plan is to binge-watch apocalyptic movies, starting with a classicRomero's Night of the Living Dead-followed by the woefully underrated Night of the Comet. After a lovely late morning start, I'll watch Outbreak and cheer as the two protagonists try to catch the Capuchin monkey from Friends so they can find the cure that'll save the world. I'm not thinking about my students, and my students are not thinking about me because SPRING BREAK is in a week and a few days! Yeah, I know there's a possibility of a pandemic... but H1N1 was a pandemic, and we're all fine. - Angie

I'm an assistant professor at the University of Minnesota Rochester (UMR), a health sciences campus connected via skyway to a world-renowned hospital. My initial training as an undergrad was in bioanthropology before I decided to reorient myself to work in community health promotion. Junior and senior students are introduced to community-based participatory research and health through sociology, anthropology, public health, and qualitative research methods in my required-forgraduation-non-STEM class. It was a few days before spring break, and I decided to put grading out of my mind by watching the end of humanity on film. Reis Fihlo suggests zombie movies are " $[\mathrm{t}] \mathrm{he}$ perfect expression of fears related to a viral apocalypse" $(2020,256)$ since a human survival plot serves as an emotional tool to cope with thoughts of our mortality (Rieger and Hofer 2017). Thus, watching Outbreak was my way of telling myself the world was not nearing a pandemic because the nerds science-types always have a solution. This was one of the most American things I did. I was trusting others to come up with a solution to the coronavirus before it reached this continent. Louder for those in the back: I, a Woman of Colour, raised by a family involved in the civil rights movement, living in Trump's America, was placing my survival in someone else's hands. This was denial with a 
nice dollop of Generation X's “don't trust anyone over thirty” attitude; which is hilarious because I am over thirty.

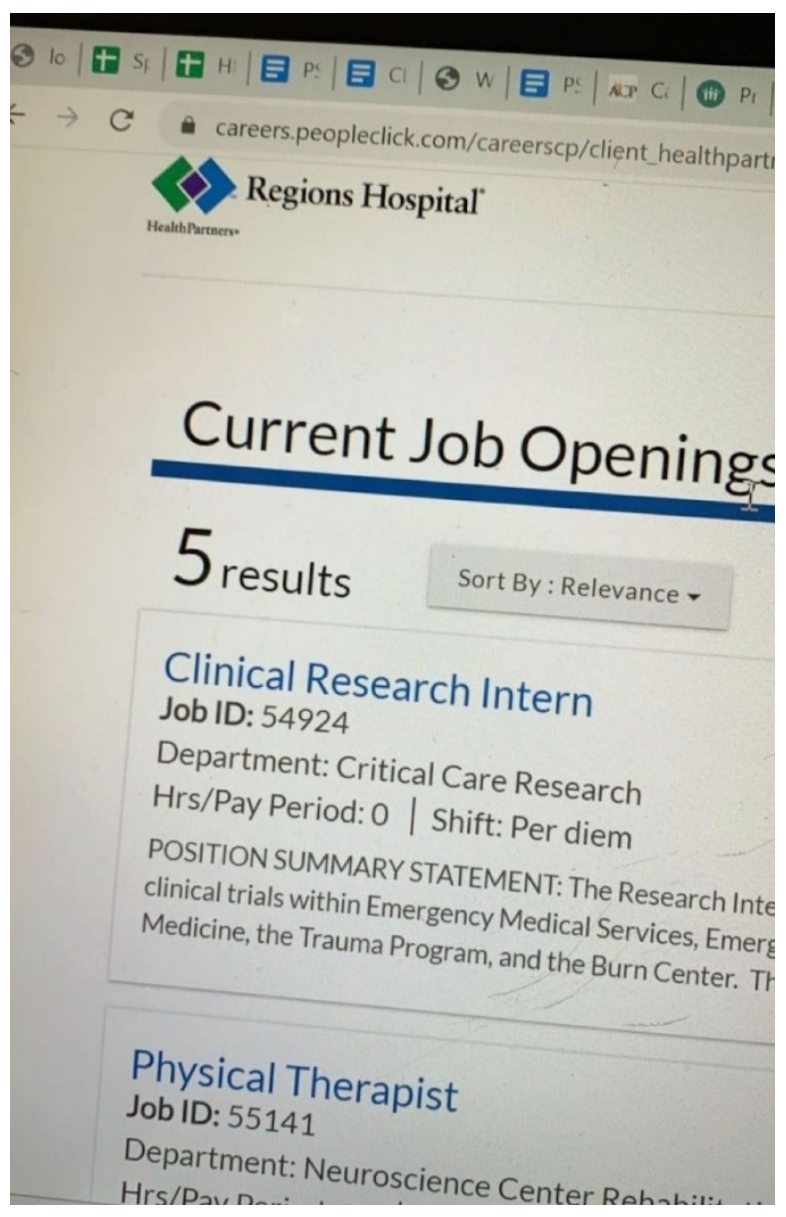

Figure 1: Planning my break ... sort of. Photo: Blake Peterson.

\section{Planning (Pre COVID-19) Futures}

26 February 2020: The Job and Internship Fair is in a couple of days; so, I'm frantically looking at the list of employers attending. I have found several positions in clinical psychology research as well as applied counseling and therapy. A job fair is a welcome relief from an already hectic semester. It allows me to look towards the future and start planning a life that does not revolve around finishing five assignments before a Friday at midnight due date. - Blake 
The last two years of a UMR undergraduate student's weekly schedule often looks like this: work part-time, volunteer, do homework, and, as it can be seen from all the open tabs above, take an overload of course credits. Repeat that again until graduation. For many of us, weekends are nonexistent. At the end of the day, we have little time to socialize or take time off. It is common to continue working at this speed during our breaks. In fact, many of us are collaborating on this manuscript while attending accelerated summer classes, preparing for conferences, working in research labs, or attending training for additional credentials or certifications. Sometimes all at once. A day in late February, just before spring break which many of us would probably use to catch up with homework, made the prospect of an internship fair a lovely sort of break. At that time, I knew that COVID-19 was in other countries, but there was no immediate concern for Minnesota's population, so the fair went on without a second thought. 


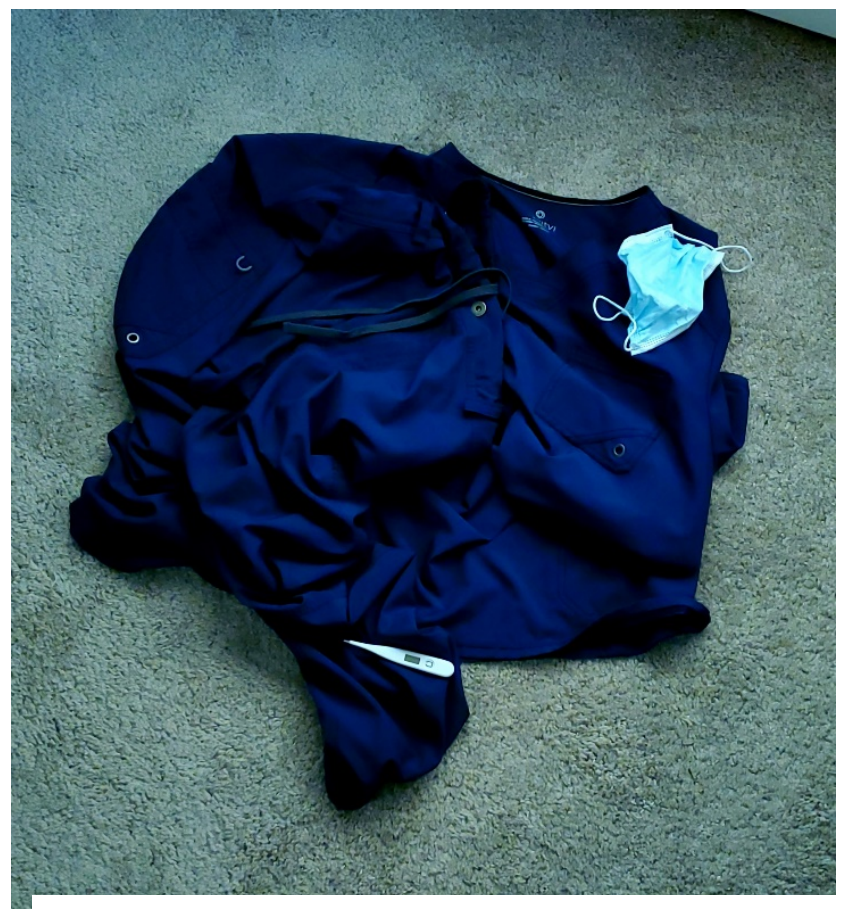

Figure 2: Wishing I could discard a day's worth of worries as easily as this uniform. Photo: Daniel R. Turin.

12 March 2020: A few days ago, I heard about COVID-19's landfall in Minnesota. I was preparing for my hospital shift as a healthcare technician when I got a notification on my phone. The fourth case of COVID-19 in Minnesota was now in Olmsted County. "What if I see that patient this evening?" "What if I accidentally catch it?" "Was I carrying this?" "Was that small throat-clear COVID-19 in my lungs?" "Had something from the hospital hitched a ride in my lungs, waiting to pounce on those I interact with?" "I had heard young people might not even show symptoms. Where did I hear that?" - Daniel

That day in March epitomized a sense of dread and helplessness that are now part of the internal dialogue of many healthcare staff; our fears of becoming infected and infecting others. Studies have shown that feelings of guilt and fear, not only of getting the virus but also of having to leave one's job, 
are not uncommon among healthcare staff (Walton, Murray and Christian 2020). As I began filtering through that past week's immunology lecture on viruses, I recalled how easily they could spread and take over. As I went between patients, there was a sense of unknowing and apprehension that I felt on behalf of myself and the patient. Patient after patient; seeing transplantees, cancer survivors, and older adults. I also remember pelting my more experienced co-workers with questions about how the hospital had dealt with SARS and even Ebola. Returning home after my shift, I threw my scrubs on the floor and tried to sleep with the day's events on loop in my dreams. As I woke and prepared to visit my parents, my fears collided; instead of jumping between patients during the shift, I was going home to my parents, including my mother, a five-year post-transplant patient.

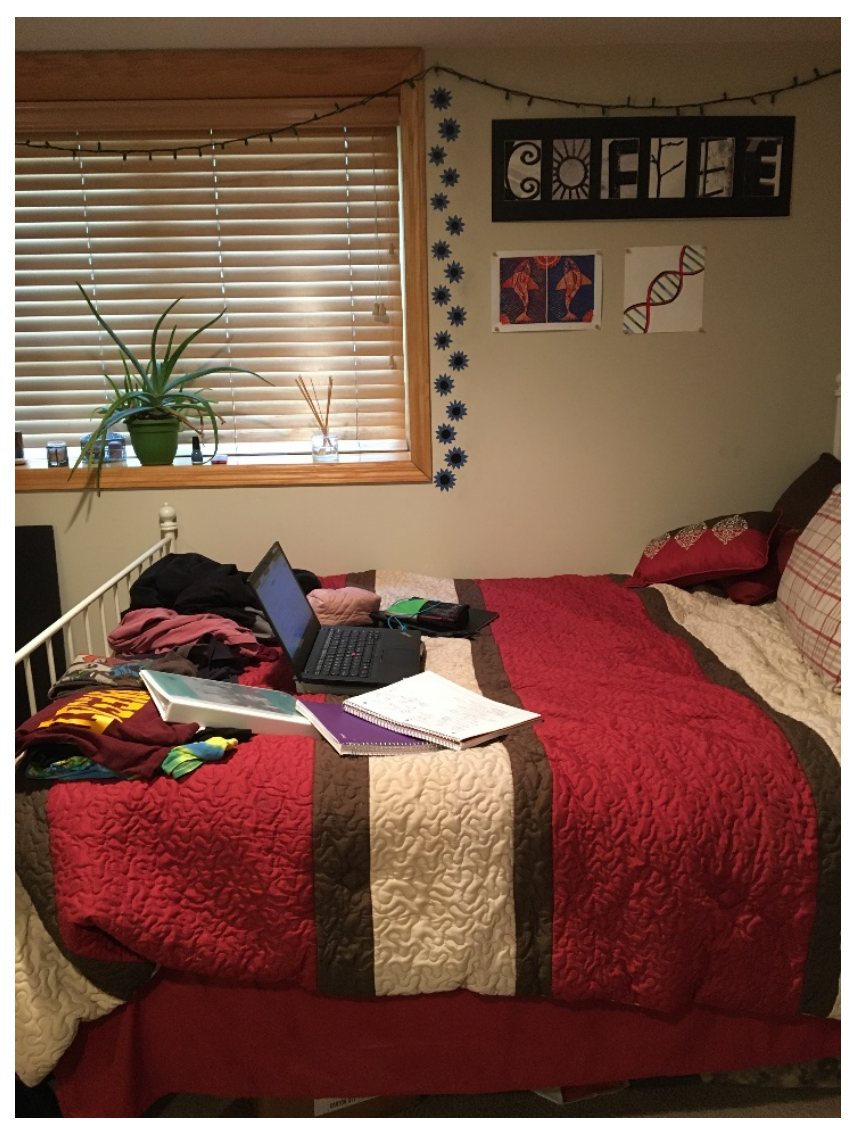

\section{A Room Not of Her Own}

Figure 3: Making the best of the current situation. Photo: Fiza Khan. 
23 April 2020: Finally done with Neuropsychology. My laptop sits atop my old textbooks (I guess they've served a purpose after all) and my clean laundry. I'm scrambling because I've fallen behind on my laundry while the rest of my family decided to do theirs too. Sitting in a messy workspace while Zooming into my lecture is not the greatest but there is no other way. I've struggled to separate home issues from school ones, but this is now practically impossible as I'm going to school where I sleep. Also, I have four days left before a research paper is due. I prefer to work and study away from my living space because it can be challenging to focus. Now I have to confine myself to my room at home, a room not of my own, which also needs to serve as a classroom/study space while my family takes over the rest of our home. - Fiza

My experience does not approximate what Boncori (2020) called the "never-ending shift," of being a woman during a pandemic while having to work from home and take care of children and other family members. I do not have children nor I am solely responsible for my family's needs. However, my picture highlights the blurring of lines between my health sciences student self and my young woman self. As we worked on an earlier version of this essay, I compared my desk set-up to other people's pictures. Some of us noticed a clear gendered divide: some workspaces showed a dedicated working space with no evidence of a room that stored everyone else's folded laundry. My area shows that I have to figure out how to learn, go to class, do homework, and seek summer internships while in a living area for others in my household. While some see the pandemic as a moment where we might notice a change in, or at least a significant relaxation, of how we do gender (Wenham, Smith and Morgan 2020), many others argue that the usual burdens placed on women inside and outside of the household, especially frontline workers, will most likely worsen due to the pandemic (McLaren, et al. 2020). 


\section{What Good Am I Now?}

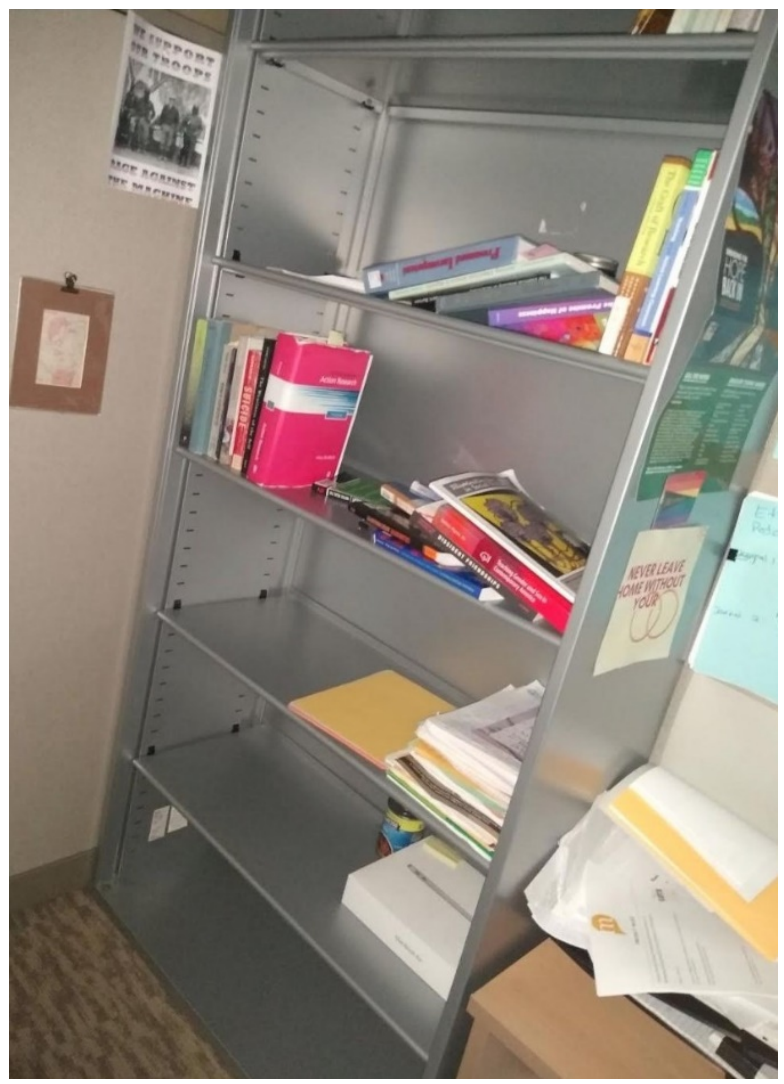

Figure 4: Past lives. Photo: Angie Mejia.

8 May 2020: I have returned to my faculty office to pick up the last remaining books and I want to cry: Old to-do lists outlining projects with students and posters from a conference that was canceled are all that remains. Once a space to plan community-based and studentled research, this office is now disordered and chaotic, reminiscent of montages at the beginning of dystopian movies that I may have watched while denying that pandemics were real. - Angie

David Ansari, writing about teaching a class on the social determinants of health in times of Corona, wonders how this experience will position him and his students "to rethink the ways [they] engage with one another" (2020). This image encapsulates similar anxieties that I, the person who teaches Community Collaborative, the non-STEM-class-needed-to-graduate-taught-by-the-professor- 
that-many-years-ago-worked-in-some-sort-of-lab-I-think, am now forced to evolve. What do I do for my students? In addition to creating ways to deliver curriculum online, I need to restructure my whole approach to community engagement while Zooming in from home. But more importantly, I am also forced and forcing myself to think of how I will give my students hope as they go into a changing healthcare system. All this, while I have no hope left in me. Our students tend to develop strong mentoring relationships with their professors, coming to us with questions beyond academics as they carefully plan out their post-baccalaureate futures. Yet, here I am, on the verge of tears because I have nothing of value left to offer at a time that they might need some of my so-called wisdom the most.

\section{Communicating Corona}

10 May 2020: This weekend's conversations with my dad revolved around COVID-19 and whether it's a serious health threat or not. The long and short of it: it is hard discussing disease transmission facts with a middle-aged man. COVID-19 can be deadly to him and his parents, whom he visits regularly. Yes, it is hard and laborious work communicating Corona. At the same time, my father repeatedly expresses his belief that the media and health officials are over-exaggerating the severity of the pandemic. Like many "small-town America" citizens, he believes the virus is too politicized. Yet, I find it essential to stay up-to-date with information so I can share it in an understandable way. And I will continue to help my dad see my side and the science behind the virus, but it is an uphill battle. - Blake

As a health sciences student, applying to graduate school and on the job market, making sense of COVID-19 has driven home the need to deliver life-saving information, even if it means challenging the opinions of those who raised you. Atlani-Duault and colleagues suggest that, in this time of Corona, trust in scientific discourse and the expertise of those who deliver it has been "put to the test" (2020, e137) People's behaviors around mask-wearing, among other variables, have the rest of us 
bearing the burden of increasing COVID-19 cases. None of my classes prepared me to deal with the many ways people receive, analyze, and trust public health information. I was not told how $I$ would be put to the test. I have not been shown how to engage in the effective delivery of health information to a public already bombarded with contradictions. Not even in Professor Angie Mejia's class, where I would have expected this knowledge to be imparted, was I warned that my scientific training in disease transmission would be met with distrust from others, even those close to me.

\section{Science Versus Everyone Else}

25 June 2020: Stumbling across US governmental denials and misinterpretation of scientific language while aimlessly perusing social media is a jarring reality check. Seeing scientists and experts undermined while trying to solve a health crisis is something I cannot fully grasp. There are many controversial topics under the broad umbrella of science, and, unfortunately, the objective nature of our discipline has been marred. Science is a process. Those who engage in it are not liars, nor are they untrustworthy; as their understandings change and findings evolve, health policies and practices adjust accordingly. It is difficult to helplessly watch as our leaders miss this fundamental understanding while disregarding public health findings and sidelining scientists. - Fiza

"Then, whom can we trust?" is what I hear others say or see them type. I listen to what the experts are telling us because I trust the process. But trusting it is easy for $m e$; convincing the people around me to do so is exceptionally challenging when they all pay attention to outrageous conspiracy theories and listen to everyone but scientists and public health professionals. Before the pandemic, Professor Angie Mejia started her lecture on social medicine with a quote by Michel Foucault, in which he states that the role of the doctor, in our case, anyone working as a health science professional, is one of political work first and science and medicine second. Some of my classmates disagreed with 
this statement. Still, maybe the line "the struggle against disease must begin with a war against bad government," (Foucault 1994, 33) rings true now more than ever. Policy researchers argue that our best chance to contain the spread is at the local level, with governmental officials, public health and medical professionals, community organizations, and the public collaborating (Carter and May 2020) to mitigate the pandemic. If our role as future health scientists is changing, becoming even more challenging because those in power refuse to listen, then what rules and guidelines should we be following?

\section{Is It Me or Is It Them?}

9 July 2020: Corona cases in Minnesota have been steadily rising. News reports are showing downtown opening up and some nightlife returning. Some friends, tired of sheltering at home, caved and went to celebrate someone's 21 st birthday. As health sciences students, we learn how fast viruses can spread and understand the impact of transporting them back to our communities. Seeing friends out celebrating, without masks, is sparking a moral debate for me. Was I stingy and overly cautious by staying home? On top of that, I am frustrated at seeing so many people gathering in downtown "MedCity" as if there was no pandemic. Daniel

Fluctuating feelings around risk and safety in response to the health behaviors of others are normal responses to changes "to a previously coherent self-narrative" (Zhu and Zheng 2020, 8) that defined our pre-Corona lives. Chandi, Fiza, Blake and I were either ready to graduate or planning out our last year. We lived by the rhythm of our exams, labs, and internships while juggling extracurriculars that would make us more competitive to employers and medical school admission committees, despite wanting to enjoy moments and be "normal" college students. Our lives are now defined by so many changes that we barely have time to understand what might be coming next. The 
cacophony of messages invalidating scientific sources of knowledge forces us to stop and reflect upon our beliefs, not only as students trained in the sciences, but also as young adults who, up until now and unlike many others, have followed the rules - of the lab, the classroom, the workplace, of our homes, and rules that the rest of society has told us to follow if we are to fulfill our professional goals of someday working as healthcare providers and science professionals.

\section{Inside and Outside}

Figure 5: While I am inside debating my role, this poster, standing for the activism I believe in, sits

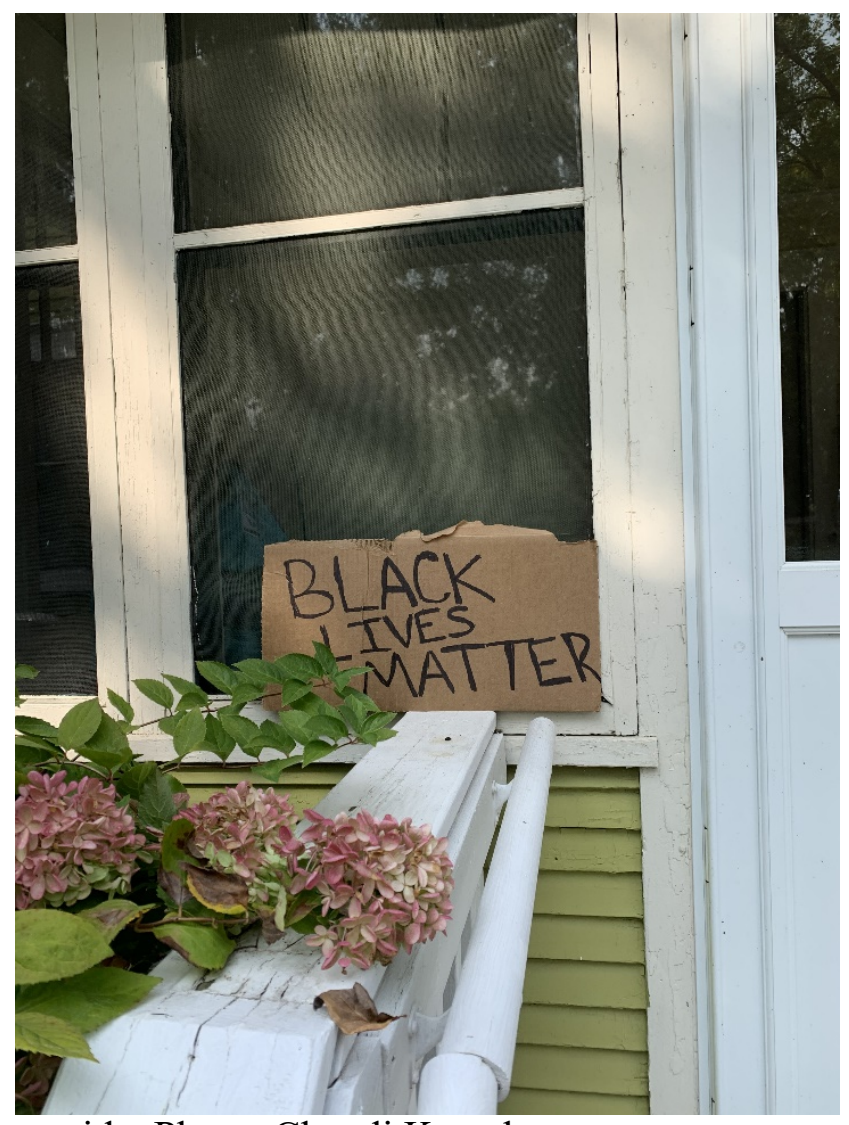

outside. Photo: Chandi Katoch.

11 July 2020. As if a pandemic and rigorous pre-med coursework were not enough to handle, news broke of the murder of George Floyd at the end of May 2020. Murdered just 81.3 miles from my house, Floyd's death has ignited conversations and protests against police brutality 
across the world. As an activist, Woman of Colour, and essential healthcare worker, I'm conflicted. As an advocate, I'm urged to join my community and (quite literally) stand up to the racist systems that aid and abet police brutality. However, a pandemic is raging, and I work with people at high risk of adverse outcomes if they were to contract COVID-19. How do I advocate for the dismantling of racist systems that are killing people without risking the lives of the people I work for? However, I refuse to just sit inside my house and wonder. I've reached out to Dr. Mejia to vent and asked her to collaborate on an opinion piece for a local newspaper that was equally cathartic and a call to action. - Chandi

As we have been preoccupied with COVID-19 it seems like the rest of the world has been put on pause. Then, George Floyd was murdered by Minneapolis police, and we are reminded of the violence, racism, and police brutality that have plagued some of our communities long before Corona. As people crowded Minneapolis streets, shoulder-to-shoulder, to protest police brutality and demand justice, COVID-19 was put on the backburner. Some protesters were not wearing masks, and the sheer number of people made safe social distancing nearly impossible. Assembling in such a way to demand justice for George Floyd, Breonna Taylor, Ahmaud Arbery, and all of the other BIPOC (Black, Indigenous, and People of Colour) killed at the hands of police seems justified in any other time, but what about during a pandemic? Research shows that these communities are disproportionately affected by COVID-19. Even though the disease does not discriminate, our healthcare system does in complex ways, with BIPOC facing further challenges related to access and other social issues contributing to inequities (Tai, et al. 2020). Though the folks coming together with the Black community may have good intentions, is putting people at risk to fight injustices justifiable? Or are there other ways that we can fight one wicked problem without worsening another? 


\section{On Autoethnography and Vulnerability}

For most of us, writing an autoethnography during our last year of undergraduate training would provide the opportunity to develop the emotional-intellectual space to step back and reflect on the implications of a pandemic on our future educational and career plans. Although we had early reservations about this project, three of the four methodological moves that differentiate an autoethnography from other forms of biographical writing - the use of personal experience to analyze and critique the current social moment, to add to the existing body of literature, and to nurture a transformative relationship between autoethnographer and their audience — seemed necessary during a time where decisions about the collective health of our nation were shaped by political decisions founded on scientific mistrust. However, that fourth methodological move that separates an autoethnography from other reflexive texts - the use of vulnerability with an intention to move and evoke something in the reader-made us pause and wonder about the consequences of this piece to us and those around us.

All of us are in different positions along our professional trajectories but we all know what it is to inhabit and navigate some form of vulnerability or precarity — the corresponding author is an untenured professor; the rest of us are undergraduates applying to graduate and medical school while working part-time as healthcare workers. Some of us felt that the writing of this piece might negatively influence those making decisions about our futures; others had to weigh in whether writing autoethnographic recollections that critique the world around us would affect our connections to others. In all, vulnerability with intentionality may cause writers, especially those in health sciences, medicine, or STEM, to pause, doubt their truths, or altogether abandon their forays into autoethnography. 
To put it another way, the methodological practice of writing with vulnerability is mutually incompatible with the positivist paradigms within STEM, health sciences, and medical research that have defined our educational and professional trajectories. Those of us still learning about this method have not been trained to envision embracing the unpredictability of vulnerability as a tool to write. We would not have been comfortable with the many losses that might come from publishing personal writing that is, at times, raw, unapologetic, and always revealing something that puts the writer at risk. However, as we wrestled with these anxieties of being judged and scrutinized, it became clear how the potential "synergism between scientific principles and those of social justice" (Khan, et al. 2012, 388), which has animated our desires to enter medicine, science, or community-based health research, is compromised when we forget how vulnerability operates and affects the health of the collective. The social moment at the heart of this autoethnography is a testament of not only how our communities are vulnerable to political decisions that prevent the scientific and medical community from controlling this pandemic, but those individuals, groups, and institutional formations that make up the scientific and medical contexts that we find ourselves in and defines our work are now in a state of vulnerability.

Further, this vulnerability with intentionality that shapes autoethnographic methods, and taking into consideration those professionals in science and medicine who chose to embark in this project, might open the possibility of creating and illuminating counternarratives that "talk back" (hooks 1989) to what the rest of the American public is being told (or not) about science, public health, or healthcare professionals working with COVID-19 patients. All of us, except the corresponding author, have and continue to work at the various frontlines of this pandemic. Yet, the out-of-control COVID-19 realities we face remain in the clinical space, at the interpersonal level, between co-workers or fellow students, and almost always, away from public knowledge and understanding. Thus, it is within that intentional 
vulnerability where we might aspire, in the classroom, lab, or clinic, to "meet in a healing, common humanity" (Foster 2013, 22) with others to then collectively address the effects of this pandemic.

\section{Imagining Normality or Creating Worlds Anew?}

In addition to community-building, we can transform our world by imagining it differently, dreaming it passionately via all our senses, and willing it into creation. - Gloria Anzaldúa $(2009,312)$

Being vulnerable allowed us the freedom to build a community in which people not only care for each other but support one another and others as they imagine better worlds and ways of caring for one another in our worlds. Now, if we are to follow Gloria Anzaldúa's message to its fullest, how do we imagine and will these new worlds into existence? As a practice of making and maintaining connections (Ellis and Rawicki, A Researcher and Survivor of the Holocaust Connect and Make Meaning during the COVID-19 Pandemic* 2020), a collaborative autoethnography was our first step in envisioning something new. Instead of ruminating in isolation and submitting ourselves to this "new normal," we agreed to make sense of COVID-19 together, as writers. Cooped up inside our bedrooms and using Zoom to talk about a pandemic summer, we noticed that, in analyzing our reflections, we were moving beyond resignation and into a constant state of refusal. The flows and shifts of this text highlight how rejecting the usual calls to accept the language of the "new normal" while creating sustainable ways of supporting each other by writing with all our emotions and communicating painful truths is one way to break free and dream again.

Once we imagine what these new worlds and ways—of doing, connecting, and living with others-look like, how do we move while moving others, from planning worlds and practices into building these into reality? We hope this text encourages others to examine similar anxieties and think of better practices for the future; to think of ways of creating new worlds, making them not only visible 
but achievable, whether by writing or other mediums. For us, making these experiences public and visible, and putting into practice these lessons we have learned while riding the coronacoaster, is our way to contribute to an affective and radical sense of hope that we and others, online and offline, are creating.

\section{References}

Ansari, David. 2020. "Teaching the Social Determinants of Health during the COVID-19 Pandemic." Somatosphere (Blog). March 27. http://somatosphere.net/2020/teaching-social-determinants-healthcovid19.html/.

Anzaldúa, Gloria. 2009. "Let Us Be the Healing of the Wound: The Coyolxauhqui Imperative -- La Sombra y El Sueño." In The Gloria Anzaldúa Reader, edited by AnaLouise Keating and Gloria Anzaldúa, 303-17. Durham, NC: Duke University Press.

Atlani-Duault, Laëtitia, Jeremy K. Ward, Melissa Roy, Céline Morin, and Andrew Wilson. 2020. "Tracking Online Heroisation and Blame in Epidemics." The Lancet Public Health 5 (3): e137-38.

Boncori, Ilia. 2020. "The Never-Ending Shift: A Feminist Reflection on Living and Organizing Academic Lives during the Coronavirus Pandemic." Gender, Work \& Organization 27 (5): 677-82. https://doi.org/10.1111/gwao.12451.

Carter, David P., and Peter J. May. 2020. "Making Sense of the U.S. COVID-19 Pandemic Response: A Policy Regime Perspective." Administrative Theory \& Praxis 42 (2): 265-77.

Chang, Heewon, Faith Ngunjiri, and Kathy-Ann C. Hernandez. 2016. Collaborative Autoethnography. Walnut Creek, CA: Left Coast Press.

Ellis, Carolyn. 2004. The ethnographic I: A methodological novel about autoethnography. Walnut Creek, CA: AltaMira Press.

Ellis, Carolyn, and Jerry Rawicki. 2020. "A Researcher and Survivor of the Holocaust Connect and Make Meaning during the COVID-19 Pandemic*" Journal of Loss and Trauma 25 (8): 605-22. https://doi.org/10.1080/15325024.2020.1765099.

Ellis, Carolyn, Tony E. Adams, and Arthur P. Bochner. 2010. "Autoethnography: An Overview [40 paragraphs]." Forum Qualitative Sozialforschung / Forum: Qualitative Social Research 12 (1): Art. 10. http://nbnresolving.de/urn:nbn:de:0114-fqs1101108.

Foster, Elissa. 2013. "Values and the Transformation of Medical Education: The Promise of Autoethnographic Research." Journal of Medicine and the Person 11 (1): 19-23. https://doi.org/10.1007/s12682-013-01425.

Foucault, Michel. 1994. The Birth of the Clinic: An Archaeology of Medical Perception. Translated by M. Sheridan. New York: Vintage.

Holman Jones, Stacy. 2005. "Autoethnography: Making the personal political." In Handbook of qualitative research, edited by Norman K. Denzin and Yvonna S. Lincoln, 763-791. Thousand Oaks, CA: Sage.

Holman Jones, Stacy, Tony Adams, and Carolyn Ellis. 2013. "Introduction: Coming to Know Autoethnography as More than a Method." In Handbook of Autoethnography, edited by Stacy Holman Jones, Tony Adams and Carolyn Ellis, 17-48. Walnut Creek, CA: Left Coast Press.

hooks, bell. 1989. Talking Back: Thinking Feminist, Thinking Black. Brooklyn, NY: South End Press. 
Khan, Omar A., Kawika Liu, Maureen Lichtveld, and Elizabeth A. Bancroft. 2012. "Synergism of Science and Social Justice." American Journal of Public Health 102 (3): 388-89. https://doi.org/10.2105/AJPH.2011.300533.

McLaren, Helen Jaqueline, Karen Rosalind Wong, Kieu Nga Nguyen, and Komalee Nadeeka Damayanthi Mahamadachchi. 2020. "Covid-19 and Women's Triple Burden: Vignettes from Sri Lanka, Malaysia, Vietnam and Australia." Social Sciences 9 (5): 87.

Mejia, Angie. 2020. "Community-Engaged Learning in Times of COVID-19, or, Why I'm Not Prepared to Transition My Class into an Online Environment." Public Philosophy Journal 3 (1). https://doi.org/10.25335/ppj.3.1-3.

Raimondi, Gustavo A. 2020. "Between Applauses and Loneliness, Heroes/Warriors and Fear: Thoughts of a Medical Professor During the COVID-19 Pandemic." Qualitative Inquiry.

Reis Filho, Lúcio. 2020. "No Safe Space: Zombie Film Tropes during the COVID-19 Pandemic." Space and Culture 253-58.

Rieger, Diana, and Matthias Hofer. 2017. "How Movies Can Ease the Fear of Death: The Survival or Death of the Protagonists in Meaningful Movies." Mass Communication and Society 20 (5): 710-33.

Tai, Don Bambino Geno, Aditya Shah, Chyke A, Doubeni, Irene G. Sia, and Mark L. Wieland. 2020. "The Disproportionate Impact of COVID-19 on Racial and Ethnic Minorities in the United States." Clinical Infectious Diseases: An Official Publication of the Infectious Diseases Society of America. doi:10.1093/cid/ciaa815.

Walton, Matthew, Esther Murray, and Michael D. Christian. 2020. "Mental Health Care for Medical Staff and Affiliated Healthcare Workers during the COVID-19 Pandemic." European Heart Journal: Acute Cardiovascular Care 9 (3): 241-47.

Wenham, Clare, Julia Smith, and Rosemary Morgan. 2020. "Covid-19 Is an Opportunity for Gender Equality within the Workplace and at Home." BMJ 369 (April). doi: 10.1136/bmj.m1546.

Yarrow, Emily, and Victoria Pagan. 2020. "Reflections on Front-Line Medical Work during COVID-19 and the Embodiment of Risk." Gender, Work \& Organization. https://doi.org/10.1111/gwao.12505.

Zhu, Peitao, and Yinghe Zheng. 2020. "Constructivist Retelling of the Epic of Gilgamesh: Implications for the COVID-19 Pandemic." Journal of Constructivist Psychology 1-9. https://doi.org/10.1080/10720537.2020.1786867. 